\title{
Valorization of rice straw waste: an alternative ceramic raw material
}

\section{(Valorização de resíduo de palha de arroz: uma matéria-prima cerâmica alternativa)}

\author{
Á. Guzmán $A^{1^{*}}$, S. Delvasto $A^{1}$, E. Sánchez $V^{2}$ \\ ${ }^{1}$ CompositeMaterials Group (Grupo de Materiales Compuestos - GMC), Escuela de Ingeniería de Materiales, \\ Facultad de Ingeniería, Universidad del Valle, Calle 13 \# 100 -00, Edif. 349, Cali, Colombia \\ ${ }^{2}$ Instituto de Tecnología Cerámica - ITC, Universidad Jaume I, Campus Universitario Riu Sec \\ [James I University, Castellón, Spain. Campus Riu Sec], Av. VicentSosBaynat s/n, 12006 Castellón, Spain, \\ *alvaro8308@hotmail.com,silvio.delvasto@correounivalle.edu.co,enrique.sanchez@itc.uji.es
}

\begin{abstract}
In the production of rice a large amount of solid residue is produced, for which alternative utilizations are scarce or are not commonly applied in industry. Rice straw (RS) is a waste product of rice harvest that is generated in equal or greater quantities than the rice itself. RS is frequently burned in open air, which makes it a significant source of pollution. In the search for possible uses of RS, it should be noted that its ash (RSA) is particularly rich in silica, alkaline and alkaline earth metals and may be used as a source of alkalis and silica for the production of triaxial ceramics. The present research work proposes the production of a ceramic raw material from RS for its use in the fabrication of ceramic materials for the construction industry. Based on the chemical and mineralogical composition of RSA created under different thermal conditions, the most suitable RSA for this purpose was that obtained from treating RS at a temperature of $800{ }^{\circ} \mathrm{C}$ for a time of $2 \mathrm{~h}$. The resulting RSA presented high contents of $\mathrm{SiO}_{2}(79.62 \%)$, alkaline oxides $\left(\mathrm{K}_{2} \mathrm{O}\right)(10.53 \%)$ and alkaline earth oxides $(\mathrm{CaO})(2.80 \%)$. It is concluded that RSA is a new alternative ceramic raw material that can be used as a replacement for the fluxing (mainly feldspar) and inert (quartz) materials that are used in the production of triaxial ceramics.
\end{abstract}

Keywords: agricultural residue, rice straw, rice straw ash, construction material, triaxial ceramics.

\section{Resumo}

Na produção de arroz é produzida uma grande quantidade de resíduo sólido, para o qual usos alternativos são raros ou não são aplicados comumente na indústria. A palha de arrozé um produto residual da colheita de arroz, que é gerado em quantidades igual ou maior que a do próprio arroz. A palha de arroz é frequentemente queimada ao céu aberto, sendo uma fonte significativa de poluição. Na busca de possíveis usos da palha de arroz, salientando que sua cinza é particularmente rica em sílica, metais alcalinos $e$ de terra alcalina, e podem ser usados como fonte de álcalis e de sílica para a produção de cerâmicas triaxiais. Este trabalho de pesquisa propõe a produção de matéria prima cerâmica a partir da palha de arroz para seu uso na fabricação de materiais cerâmicos para a indústria da construção. Tendo como base a composição química e mineralógica da palha de arroz criada sob diferentes condições térmicas, a palha de arroz mais adequada para esta finalidade foi obtida tratando a $800{ }^{\circ} \mathrm{C}$ durante $2 \mathrm{~h}$. A palha de arroz resultante apresentou alto conteúdo de $\mathrm{SiO}_{2}(79,62 \%)$, óxidos alcalinos $\left(\mathrm{K}_{2} \mathrm{O}\right)(10,53 \%)$ e óxidos de terra alcalina (CaO) (2,80\%). Conclui-se que a palha de arroz é uma matéria prima cerâmica alternativa que pode ser usada para substituir fluxing (principalmente feldspato) e materiais inertes (quartzo) que são usados na produção de cerâmicas triaxiais.

Palavras-chave: resíduo da agricultura, palha de arroz, cinza da palha de arroz, material de construção, cerâmicas triaxiais .

\section{INTRODUCTION}

The world rice production per year (Oryza sativa) was estimated to be approximately 690 million metric tons for the period from 2007 to 2011 [1]. In Colombia, rice is the third agricultural product by cultivation area, and it represents $13 \%$ of the harvested area in Colombia and $30 \%$ of transitory crops. Rice production represents $6 \%$ of the value of agricultural production and $11 \%$ of all agricultural activity in Colombia [2].Rice straw (RS) is a waste product from the harvesting of this cereal and constitutes the stem, root and a fraction of the spikes. The straw is composed of cellulose, hemicellulose, lignin, ash and extraction materials. The RS mainly contains cellulose (32-47\%), hemicellulose (19$27 \%$ ) and lignin (5-24\%) [3]. Kadam, Forrest and Jacobson [4] note that for every metric ton of rice that is harvested, approximately 1.35 metric tons of RS are left in the fields. Based on these numbers, an additional 932 million metric tons of RS could be generated globally every year, of which 1.88 metric tons would be produced in Colombia. RS differs from most crop residues in its high content of silicon dioxide $\left(\mathrm{SiO}_{2}\right)$ [4]. Despite this attribute, it is frequently burned in the open air, producing air pollution, overheating, degradation of the soil, and water pollution [5]. In some instances, RS is 
incorporated into the soil as an organic fertilizer or is used as animal feed [6]. However, in the latter case, its high level of lignification and low nitrogen, vitamin and mineral contents limit its digestibility by ruminants [7]. Some authors have used RS as a source of non-wood fibers and cellulose for the production of pulp and paper as well as raw materials for the fabrication of medium-density fiberboards (MDF) [4, 8, 9]. Elwan, Attriss, Mahmoud and Salem [10] found that RS and rice straw ash (RSA) can be used as pore-forming agents in the fabrication of bricks. Additionally, Mohamed andTaher [11] and Tanglao, Javier and Robles [12] showed that the RSA can be utilized as a pozzolanic addition. Many potential uses of RS exist, but few are industrially applied. The reasons for this appear to be related to (1) technical limitations, (2) economic feasibility, related in particular to the cost of transporting the straw from the crop site, (3) supply and (4) storage problems [13]. Many authors have presented results of the chemical composition of the RSA, ranked as follows: $72.55-83.12 \% \mathrm{SiO}_{2} ; 10.06-12.60 \% \mathrm{~K}_{2} \mathrm{O}$; $1.61-3.01 \% \mathrm{CaO} ; 0.16-1.85 \% \quad \mathrm{Na}_{2} \mathrm{O} ; 1.74-2.02 \% \mathrm{MgO}$; $0.49-2.65 \% \quad \mathrm{P}_{2} \mathrm{O}_{5} ; 0.11-1.40 \% \quad \mathrm{Al}_{2} \mathrm{O}_{3} ; 0.08-0.85 \% \mathrm{Fe}_{2} \mathrm{O}_{3}$; $0.84-1.24 \% \mathrm{SO}_{3} ; 0.01-0.09 \% \mathrm{TiO}_{2}$; and an ash content of $18.63-22.10 \%$ [14 -18].

This article presents analyses of the thermal decomposition of RS and RSA using instrumental and analytical techniques, such as thermal analysis (TA), X-ray diffraction (XRD), X-ray fluorescence (XRF), and scanning electron microscopy (SEM). On the basis of these results, taking into account that the RSA is mainly composed of silica and alkaline and alkaline earth metals, its use as an alternative ceramic raw material is proposed, because is a source of alkalis and silica for the production of triaxial ceramic for use in the construction industry.

\section{EXPERIMENTAL PROCEDURE}

\section{Obtaining of RSA}

The RS originated from a variety of rice denominated Fedearroz 60 (FL 3188). It was collected at a crop field located in Jamundi (Valle del Cauca, Colombia), at an elevation of $1000 \mathrm{~m}$ above sea level. In order to design the calcination process for the straw for the adequate production of ash, thermogravimetric (TGA) and derivative thermogravimetric (DTG) analyses were performed by using a Thermal Analyzer STD Q600 V20.5 Build 15 module DSC-TGA Standard equipment by TA Instr.. A heating rate of $10{ }^{\circ} \mathrm{C} / \mathrm{min}$ was used, from room temperature up to 1100 ${ }^{\circ} \mathrm{C}$, under an oxygen flux rate of $100 \mathrm{~mL} / \mathrm{min}$.

To obtain the ash, combustion of the RS was performed in an outdoor furnace at a temperature above the fire point to remove part of the organic matter. The maximum temperature of the flame was $650-700{ }^{\circ} \mathrm{C}$, being obtained carbonized rice straw (CRS). Subsequently, the CRS was calcined in a controlled way, and its temperature was raised from room temperature to maximum temperatures of $500{ }^{\circ} \mathrm{C}$ (Process A), $600{ }^{\circ} \mathrm{C}$ (Process B), $700{ }^{\circ} \mathrm{C}$ (Process C), $800{ }^{\circ} \mathrm{C}$ (Process
D), $900{ }^{\circ} \mathrm{C}$ (Process E) and $1000{ }^{\circ} \mathrm{C}$ (Process F); the heating rate was kept constant at $10{ }^{\circ} \mathrm{C} / \mathrm{min}$ until the maximum temperature was reached and was then maintained for a residence time of $2 \mathrm{~h}$ to insure the total decomposition of the organic matter, as well as to guarantee the full development of all the physicochemical processes that take place at each of the maximum temperatures [19]. The indicators of the progress of the decomposition and of these processes were the contents of carbon, potassium, silica and chlorine in the calcined samples.

\section{Characterization of RSA}

The moisture content and loss on ignition in the RSA were determined according to the standard ASTM C114 [20]. The content of amorphous silica was determined using the Metha patent as a reference [21]. The chemical characterization was conducted by means of a chemical analysis by XRF spectrometry using a MagixPro PW-2440 Philips spectrometer. The mineralogical phases present in the samples of RSA were identified by XRD with a PANalyticalX'Pert PRO diffractometer. The samples were scanned in the range of $2 \theta=3-80^{\circ}$ at a scanning speed of $0.02 \mathrm{~s} / \mathrm{step}$, using Cuk $\alpha$ radiation at $45 \mathrm{kV}$ and $40 \mathrm{~mA}$.

The presence of functional groups of some mineralogical compounds found in the RSA was established based on Fourier transform infrared spectroscopy (FTIR). The infrared spectra were obtained in a Perkin Elmer Spectrum 100 spectrometer in transmittance mode, with scanning frequencies from 4000 to $450 \mathrm{~cm}^{-1}$. For the preparation of the sample pellets, the conventional $\mathrm{KBr}$ compression procedure was utilized.

The morphology, topography and structure of the particles were observed by SEM, using a JEOL JSM-6490LV microscope. In addition, an elemental analysis by mapping of the ash was performed by means of an energy-dispersive X-ray (EDS) spectrometer coupled to the SEM. The color of the obtained RSA was estimated by visual observation.

The behavior of the RSA as fluxing agent was evaluated by means of melting cylinders test. Samples with compositions of sodium feldspar and $50 \%$ sodium feldspar $+50 \%$ Process D $\left(800{ }^{\circ} \mathrm{C}\right)$ RSA were moisturized with water to $8 \%$ in weight (on a dry basis) by means of a sprayer. Then, the samples were shaped in a round press with a $5-\mathrm{cm}$ diameter at a pressure of $350 \mathrm{~kg} / \mathrm{cm}^{2}$, to be placed in refractory plates previously covered by a thin layer of alumina. The sintering of the samples was performed in a Carbolite RHF 16/3 oven, with a heating rate of $5{ }^{\circ} \mathrm{C} / \mathrm{min}$ up to $1280{ }^{\circ} \mathrm{C}$. The holding time at the firing temperature was $6 \mathrm{~min}$, followed by natural cooling inside the furnace. A visual inspection was performed after this test, paying special attention to whether the edges were rounded. In both cases, the aspect and opacity of the surface was indicated, taking note of the presence of dark spots or any other anomaly. The color was also recorded as white, cream, grey, dark, or very dark. As reference material was chosen a sodium feldspar commonly used as fluxing raw material in the manufacture of porcelain 
tiles in the European ceramic industry.

\section{RESULTS AND DISCUSSION}

\section{Study of the thermal decomposition of RS}

Fig. 1 shows the TGA and DTG curves of the burning of RS in an oxidizing atmosphere $\left(\mathrm{O}_{2}\right)$.

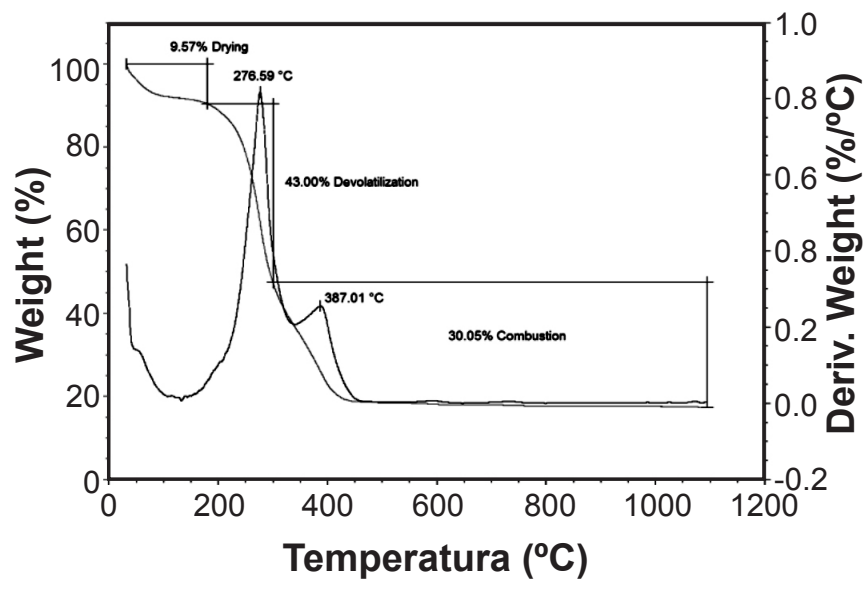

Figure 1: TGA and DTG curves of RS.

[Figura 1: Curvas TG e DTG de RS.]

The thermographs reveal three different stages in the heating process of the RS, consistent with that mentioned by Chen, Andries, Spliethoffand Leung [22] and Calvo et al. [23]. Three stages at different temperatures have been interpreted from these data.

Stage 1: Drying $\left(<180{ }^{\circ} \mathrm{C}\right)$. The first peak in the ash burning profile corresponds to the loss of hygroscopic moisture [10, 22-24]. Authors such as Calvo et al. [23] also attribute this peak to the loss of very light volatiles. Stage 2: Devolatilization $\left(180-320{ }^{\circ} \mathrm{C}\right)$. This stage began above $\sim 180$ ${ }^{\circ} \mathrm{C}$, with a weight loss attributed to the emission of volatiles from the cellulose and hemicellulose. Small amounts of volatiles from the lignin could also be given off at this stage [22-24]. Stage 3: Combustion $\left(>320^{\circ} \mathrm{C}\right)$. In this stage, the loss of weight is mainly attributed to devolatilization and the reaction between charcoal and the volatiles of the previous stages. Due to the exothermic nature of this process, the additional heat leads to the emission of the remaining volatiles as well as the rapid oxidization of the remnant combustible components [23, 24].

\section{Chemical and mineralogical composition}

The moisture content and loss on ignition values of the different rice straw ashes decreased as the calcination temperature increased (Table I). A similar behavior was observed in the amorphous silica, as shown in Table I; the amount of it is reduced as the calcination temperature increases, from the process of calcination of rice straw (CRS) up to Process $\mathrm{F}\left(1000{ }^{\circ} \mathrm{C}\right)$. With the increase of temperature,
Table I - Moisture contents, loss on ignition and amount of amorphous silica of the calcined rice straw ashes.

[Tabela I - Teor de umidade, perda ao fogo e teor de sílica nas cinzas calcinadas de palha de arroz.]

\begin{tabular}{cccc}
\hline $\begin{array}{c}\text { Calcination } \\
\text { Process }\end{array}$ & $\begin{array}{c}\text { Moisture } \\
(\%)\end{array}$ & $\begin{array}{c}\text { Loss on } \\
\text { Ignition } \\
(\%)\end{array}$ & $\begin{array}{c}\text { Amotphous } \\
\text { Silica } \\
(\%)\end{array}$ \\
\hline$C R S$ & 3.47 & 11.66 & 73.79 \\
Process $A\left(500{ }^{\circ} \mathrm{C}\right)$ & 2.66 & 8.10 & 61.30 \\
Process $B\left(600{ }^{\circ} \mathrm{C}\right)$ & 1.52 & 6.56 & 50.96 \\
Process $C\left(700^{\circ} \mathrm{C}\right)$ & 0.42 & 3.09 & 24.26 \\
Process $D\left(800^{\circ} \mathrm{C}\right)$ & 0.20 & 0.59 & 9.95 \\
Process $E\left(900{ }^{\circ} \mathrm{C}\right)$ & 0.14 & 0.03 & 5.75 \\
Process $F\left(1000^{\circ} \mathrm{C}\right)$ & 0.08 & 0.03 & 4.35 \\
\hline
\end{tabular}

the silica of RSA begins to show a more crystalline character, as corroborated by the mineralogical analysis.

The chemical compositions of the rice straw ashes (Table II) show that in addition to the present organic phase (or loss on ignition (LOI)), which varies between $11.66 \%$ in CRS and $0.03 \%$ in Process F, they are composed in their inorganic phase by a high percentage of silica $\left(\mathrm{SiO}_{2}\right)$, potassium oxide $\left(\mathrm{K}_{2} \mathrm{O}\right)$ and chlorine $(\mathrm{Cl})$, to a lesser extent by calcium oxide $(\mathrm{CaO})$, phosphorous $(\mathrm{P})$, and sulfur $(\mathrm{S})$, and to an even lesser degree by other elements such as $\mathrm{Mg}, \mathrm{Mn}, \mathrm{Fe}, \mathrm{Al}$ and $\mathrm{Na}$. These findings are in agreement with the results presented by other authors, such as Jenkins, Bakker and Wei [14], Miles et al. [15], Jenkins, Baxter, Miles Jr. and Miles [16], Thy et al. [17], and Thy, Jenkins, Lesher and Grundvig [18].

It is noteworthy that the percentage of potassium oxide $\left(\mathrm{K}_{2} \mathrm{O}\right)$ decreases with the increase of the calcination temperature, whereas the percentage of silica $\left(\mathrm{SiO}_{2}\right)$ increases. Chlorine, which is found in the form of the sylvite mineral $(\mathrm{KCl})$, is released almost in its entirety $(>93 \%)$ beyond calcination Process $\mathrm{C}\left(>700{ }^{\circ} \mathrm{C}\right)$, which coincides with what has been observed by authors such as Jensen, Frandsen, Dam-Johansen and Sander [25] and Hindiyarti [26].

The diffraction pattern of RSA obtained after $500{ }^{\circ} \mathrm{C}$ (Fig. 2) shows high-intensity peaks at angles $2 \theta=28.31^{\circ}$ and $40.46^{\circ}$, corresponding to the sylvite (KCl) (ICSD 240519). This has also been observed by other researchers, including Thy et al. [17] and Thy, Jenkins, Lesher and Grundvig [18]. In addition, at approximately $2 \theta=22.00^{\circ}$, a characteristic halo of the amorphous phase is observed.

The samples that have undergone temperature increments (Process B - Process C) present high-intensity peaks at angles $2 \theta=21.76^{\circ}$ and $35.91^{\circ}$ in the diffraction patterns, corresponding to low cristobalite $\left(\mathrm{SiO}_{2}\right)$ (ICSD 74530). This corroborates the results obtained for the percentage of amorphous silica, for which the silica begins to take a more crystalline form as the calcination temperature is increased. Starting from calcination Process D (Processes D - F), the reduction of the content of sylvite (KCl) (ICSD 240519) from the samples begins to be observed, as shown by the 
Table II - Chemical composition of the rice straw ashes obtained through the calcination processes. [Tabela II - composição química das cinzas da palha de arroz obtida nos processos de calcinação.]

\begin{tabular}{|c|c|c|c|c|c|c|c|c|c|c|c|}
\hline \multirow{2}{*}{$\begin{array}{c}\text { Calcination } \\
\text { Process }\end{array}$} & \multicolumn{11}{|c|}{ Compound and / Or element } \\
\hline & $\mathrm{SiO}_{2}$ & $\mathrm{~K}_{2} \mathrm{O}$ & $\mathrm{CaO}$ & $\mathrm{Cl}$ & $\mathrm{P}_{2} \mathrm{O}_{5}$ & $\mathrm{MnO}$ & $\mathrm{MgO}$ & $S$ & $\mathrm{Fe}_{2} \mathrm{O}_{3}$ & $\mathrm{Al}_{2} \mathrm{O}_{3}$ & $\mathrm{Na}_{2} \mathrm{O}$ \\
\hline$C R S$ & 55.16 & 15.56 & 2.72 & 8.39 & 1.33 & 0.46 & 0.80 & 0.31 & 0.20 & 0.14 & 0.09 \\
\hline Process A (\%) & 52.42 & 20.13 & 2.61 & 12.59 & 1.04 & 0.61 & 0.66 & 1.20 & 0.26 & 0.19 & 0.14 \\
\hline Process B (\%) & 69.73 & 12.22 & 4.14 & 2.82 & 1.92 & 0.91 & 0.91 & 0.27 & 0.24 & 0.14 & 0.10 \\
\hline Process $C(\%)$ & 67.73 & 15.71 & 1.65 & 3.21 & 3.51 & 0.48 & 2.46 & 1.09 & 0.36 & 0.16 & 0.42 \\
\hline Process D (\%) & 79.62 & 10.53 & 2.80 & 0.59 & 1.61 & 0.71 & 0.89 & 1.74 & 0.26 & 0.27 & 0.35 \\
\hline Process E (\%) & 85.57 & 6.68 & 3.44 & - & 1.76 & 0.77 & 0.66 & 0.08 & 0.37 & 0.28 & 0.24 \\
\hline Process F (\%) & 88.21 & 4.59 & 3.01 & - & 1.71 & 0.68 & 0.82 & 0.07 & 0.29 & 0.25 & 0.29 \\
\hline \multirow{2}{*}{ Process } & \multicolumn{11}{|c|}{ Compound and / Or element } \\
\hline & $\mathrm{Zn}$ & $\mathrm{Rb}$ & $\mathrm{Br}$ & $\mathrm{Ni}$ & $\mathrm{Sr}$ & $\mathrm{Cu}$ & $\mathrm{Y}$ & $\mathrm{Ba}$ & $\mathrm{Pb}$ & $\mathrm{TiO}_{2}$ & LOI \\
\hline $\operatorname{CRS}(\%)$ & 0.01 & 0.02 & 0.02 & - & 0.01 & - & - & - & - & - & 11.66 \\
\hline Process A (\%) & 0.01 & 0.01 & 0.01 & - & 0.01 & 0.01 & - & - & - & - & 8.10 \\
\hline Process $B(\%)$ & 0.02 & 0.02 & 0.01 & 0.01 & 0.01 & - & - & - & - & - & 6.56 \\
\hline Process $C(\%)$ & 0.06 & 0.01 & 0.01 & - & - & 0.01 & - & 0.06 & - & - & 3.09 \\
\hline Process D (\%) & 0.01 & 0.01 & - & - & 0.01 & 0.01 & - & - & - & - & 0.59 \\
\hline Process E (\%) & 0.02 & 0.01 & - & 0.01 & 0.01 & 0.01 & - & 0.04 & 0.01 & 0.03 & 0.03 \\
\hline Process F (\%) & 0.02 & 0.01 & - & 0.01 & 0.01 & 0.01 & - & - & - & - & 0.03 \\
\hline
\end{tabular}

drop in the chlorine peaks at angles $2 \theta=28.31^{\circ}$ and $40.46^{\circ}$, which is in agreement with the evidence from the XRF

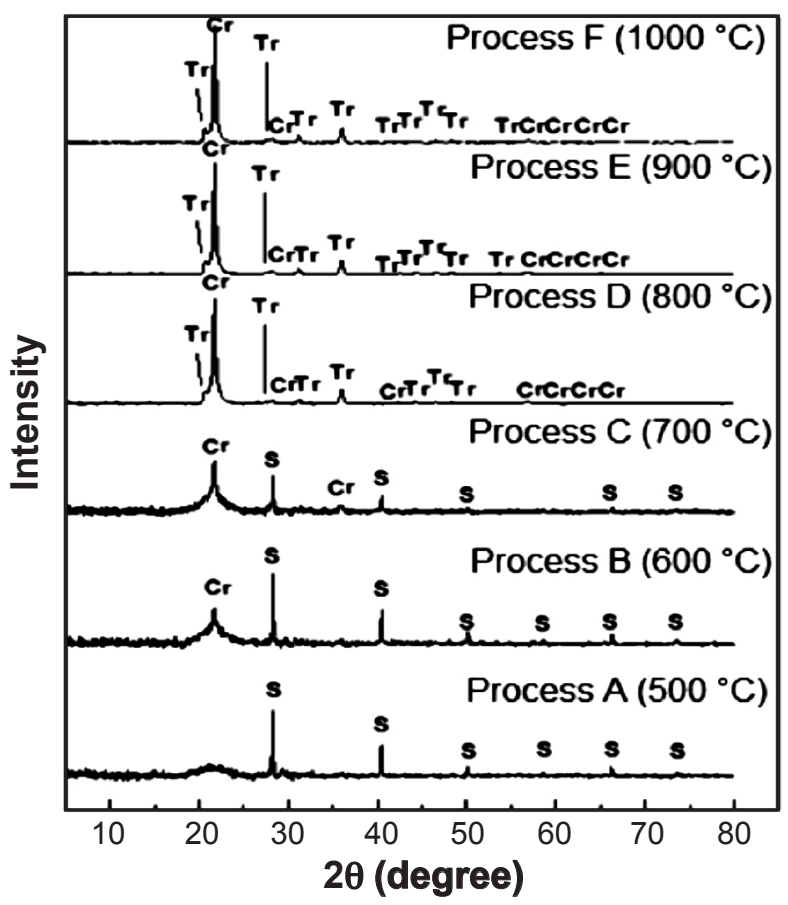

Figure 2: XRD patterns for rice straw ashes obtained from the different calcination processes. S: sylvite, $\mathrm{Cr}$ : cristobalite and $\mathrm{Tr}$ : tridymite.

[Figura 2: Difratogramas de raios $X$ de cinzas de palha de arroz. obtidas de diferentes processos de calcinação. S: silvita, Cr: cristobalita e Tr: tridimita.] analysis. It is starting from this calcination Process D that the RSA begins to show diffraction peaks corresponding to the low tridymite $\left(\mathrm{SiO}_{2}\right)(\mathrm{ICSD} 1109)$ at angles $2 \theta=20.61^{\circ}$ and $35.96^{\circ}$, tridymite appears to replace cristobalite. The replacement of the low cristobalite with tridymite has also been observed by Thy et al. [17] and Thy, Jenkins, Lesher and Grundvig [18]. This finding is in accordance with that reported by Elwan, Attriss, Mahmoud and Salem [10], who noted that the RSA is amorphous at low temperatures, going from a small crystalline state, with the crystalline phase identified as cristobalite with tridymite.

In the infrared spectra of RSA, two important regions were observed (Fig. 3), in which bands corresponding to organic functional groups above $\sim 1100 \mathrm{~cm}^{-1}$ are found, as well as bands corresponding to inorganic functional groups below $1100 \mathrm{~cm}^{-1}$.

The band at $3442 \mathrm{~cm}^{-1}$ is only observed in the RS and is attributed to the vibrations of the hydroxyl groups O-H. Fu et al. [27] and Fu et al. [28] noted that the position and the type of band suggest that the hydroxyl group is involved in the hydrogen bond. In this way, the residual water from the RS could take part in the formation of the hydrogen bonds. Three significant bands are emphasized in the inorganic part related to the $\mathrm{SiO}_{2}$, the most important being the band located at approximately $1071 \mathrm{~cm}^{-1}$, which indicates the presence of tetramers of cyclic siloxanes [29]. The existence of these tetramers is confirmed by the band located at 800 $\mathrm{cm}^{-1}$. In the inorganic part, the bands shown in the spectrum in general originate from vibrations of the aromatic part that take place in the region of $1600-1450 \mathrm{~cm}^{-1}$ (bands at 1519 


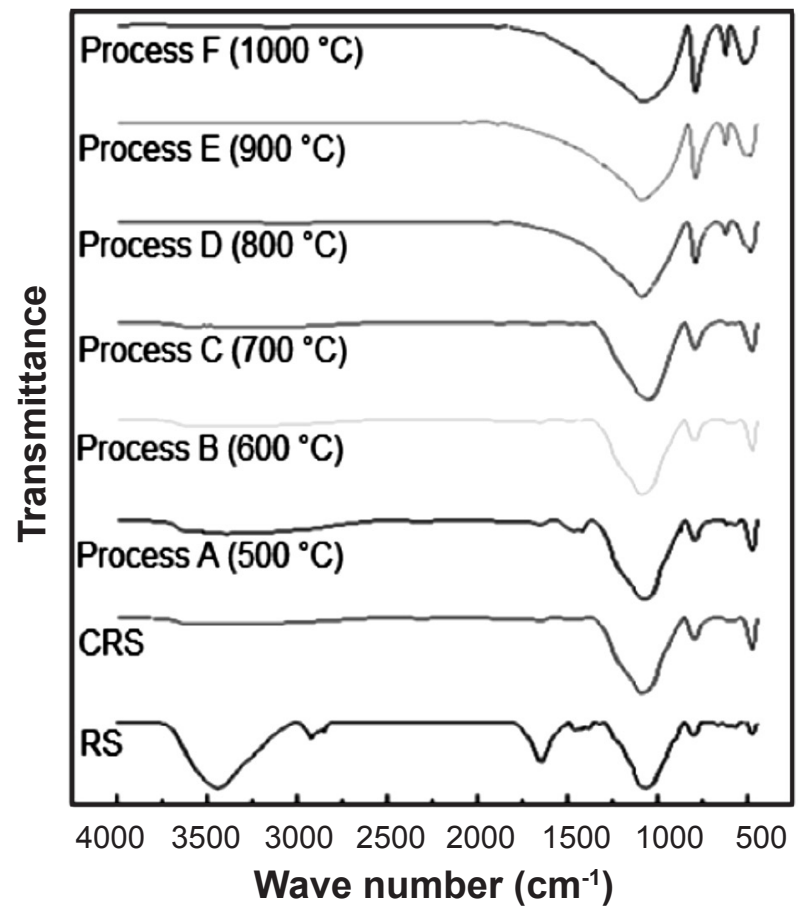

Figure 3: FTIR spectra of rice straw ashes obtained from the different calcination processes.

[Figura 3: Espectros FTIR de cinzas de palha de arroz de diferentes processos de calcinação.]

and $1461 \mathrm{~cm}^{-1}$ ), aliphatic bonds $\mathrm{C}-\mathrm{H}$ (bands at 1385 and $1432 \mathrm{~cm}^{-1}$ ), and vibrations of the carbonyl group (band at $1644 \mathrm{~cm}^{-1}$ ), which can be attributed to organic compounds such as cellulose and hemicellulose carbohydrates, as well as the lignin [3].

As the calcination temperatures of RSA samples are increased, the bands associated with the organic part begin to disappear $\left(\mathrm{T}>500{ }^{\circ} \mathrm{C}\right)$, for example, the band associated with vibrationsof the carbonyl group $\left(1644 \mathrm{~cm}^{-1}\right)$ and those located at 1385, 1432, 1519 and $1461 \mathrm{~cm}^{-1}$, which are associated with functional groups of the organic part that are decomposed and volatilized. In regards to the inorganic part, it is observed that the band located at approximately $1071 \mathrm{~cm}^{-1}$ presents a displacement to approximately 1100 $\mathrm{cm}^{-1}$, indicating that the thermal treatment favors the transformation of the cyclic siloxanes $\left(1071 \mathrm{~cm}^{-1}\right)$ into linearly bound silicon tetramers $\left(\sim 1100 \mathrm{~cm}^{-1}\right)$. This also supports the formation of a three-dimensional lattice from the union of silicon tetrahedra. Based on the previous results, the claims by Karimi, Emitiazi, Mohammad and Taherzadeh [3] about the RS being mainly composed of hemicellulose, cellulose and lignin - by functional groups of an organic nature (aldehydes constituted by a carbonyl group and aromatic compounds) - are confirmed. It is also confirmed that these are removed in their totality at temperatures above $500{ }^{\circ} \mathrm{C}$, in agreement with the results of the thermal analysis.

\section{Morphology and topography of the particles}

By means of the SEM technique, the morphology
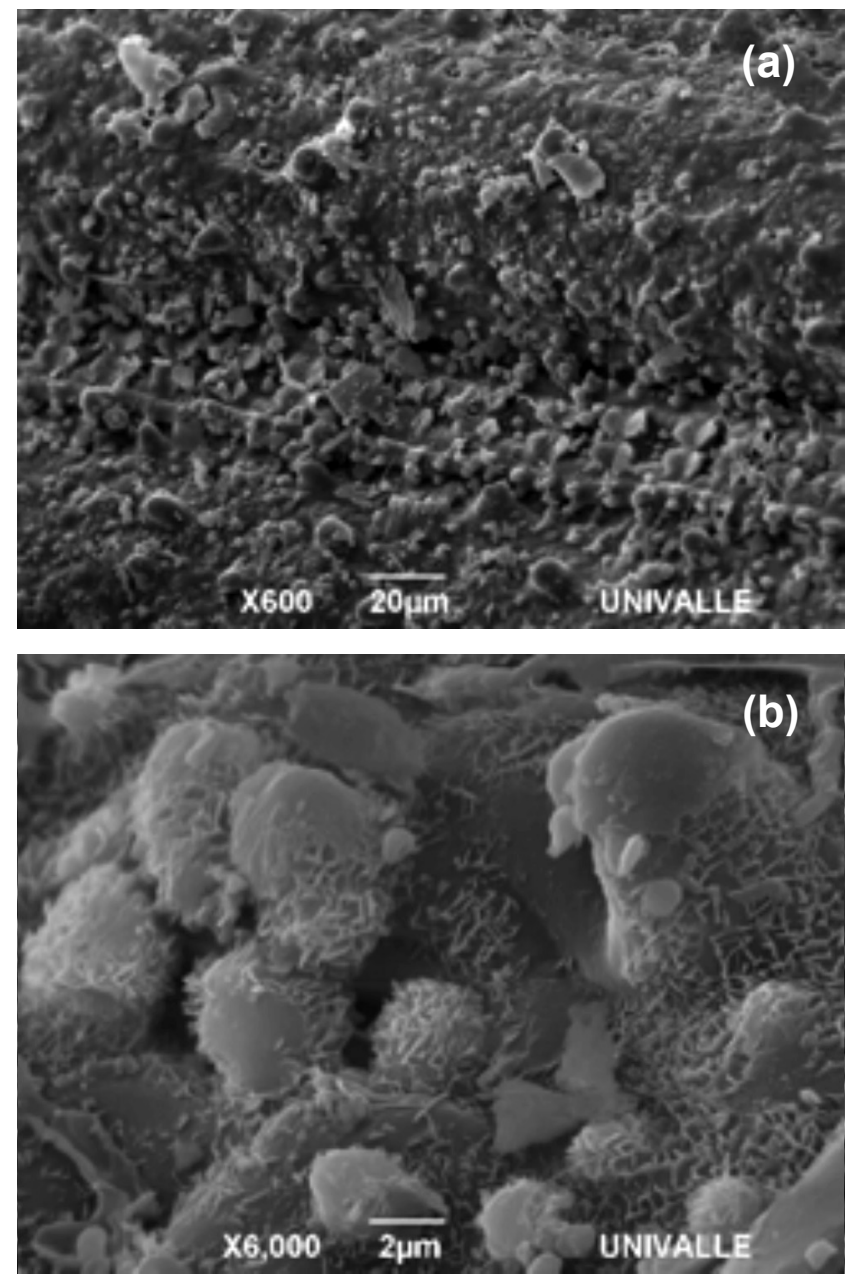

Figure 4: SEM wide view (X600) (a) and detailed view (X6000) (b) of RS.

[Figura 4: Imagem obtida por MEV: ampla (600X) (a) e detalhada (6000X) (b) da palha de arroz.

and the topography of the surface of the ashes obtained from the different calcination processes were determined. Micrographs of the ashes obtained from the calcination processes from CRS to F are presented in Figs. 4 to 11.

In the micrographs, grooves and grains are present on the surface of RS and RSA, producing a rough appearance (Figs. 4a to 11a).Analogous to what is observed in the rice husk according to reports by authors such as Arcos, Macías and Rodríguez [19], these grains correspond to silicon compounds dispersed across the surface, which was corroborated by the EDS studies performed on some rice straw ashes (Figs. 5c, 7c, 9c and 11c). Stahl and Ramadan [30] have also observed numerous silica protrusions and grains on the external surface of the stems, which may constitute a masking layer of the digestible organic material on the cell wall. The morphology of the particle surface is very rough at temperatures below $700{ }^{\circ} \mathrm{C}$. Increased calcination temperatures equal or higher than $700{ }^{\circ} \mathrm{C}$ and lower than $900{ }^{\circ} \mathrm{C}$ lead to the generation of porosity in the ash structure, which may be related to the release of volatile species, mainly chlorine, confirming what was observed in the chemical and mineralogical composition of rice straw 

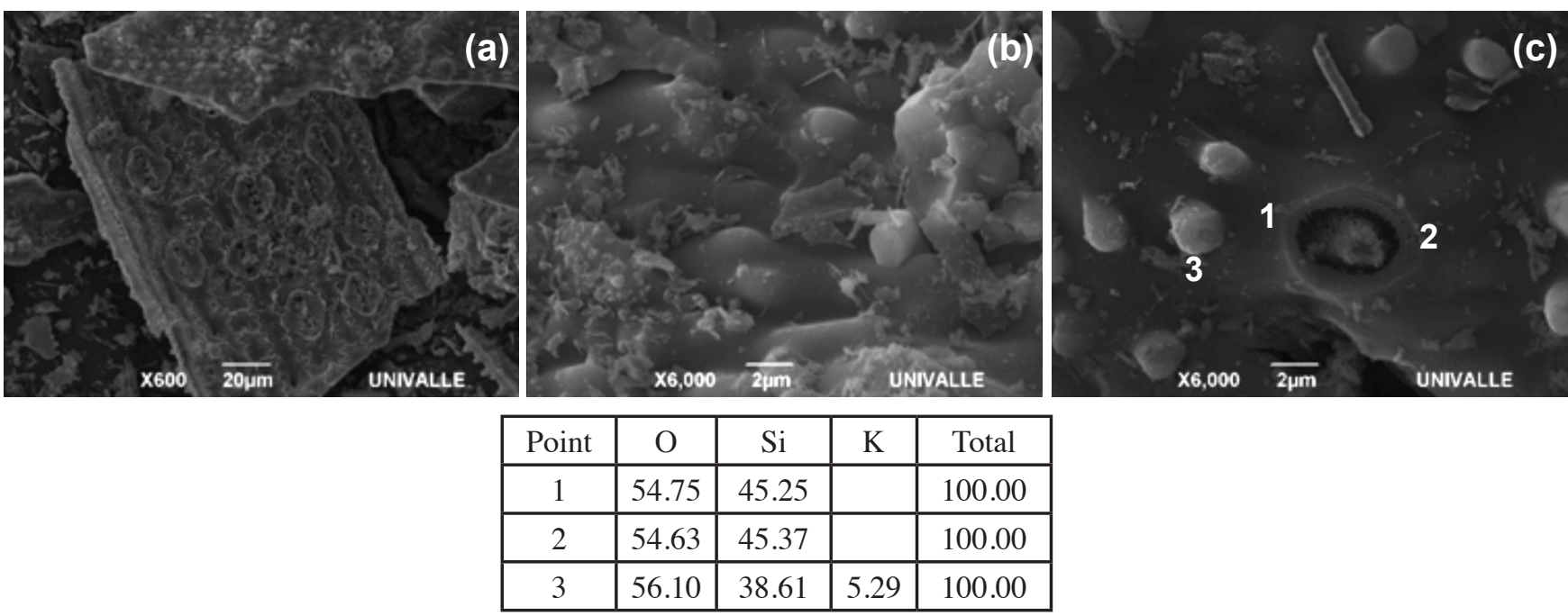

Figure 5: Wide view (X600) (a), detailed view (X6000) (b) and EDS analysis (c) of CRS.

[Figura 5: Imagem obtida por MEV: ampla (600X) (a) e detalhada (6000X) (b) e EDS (c) de CRS.]
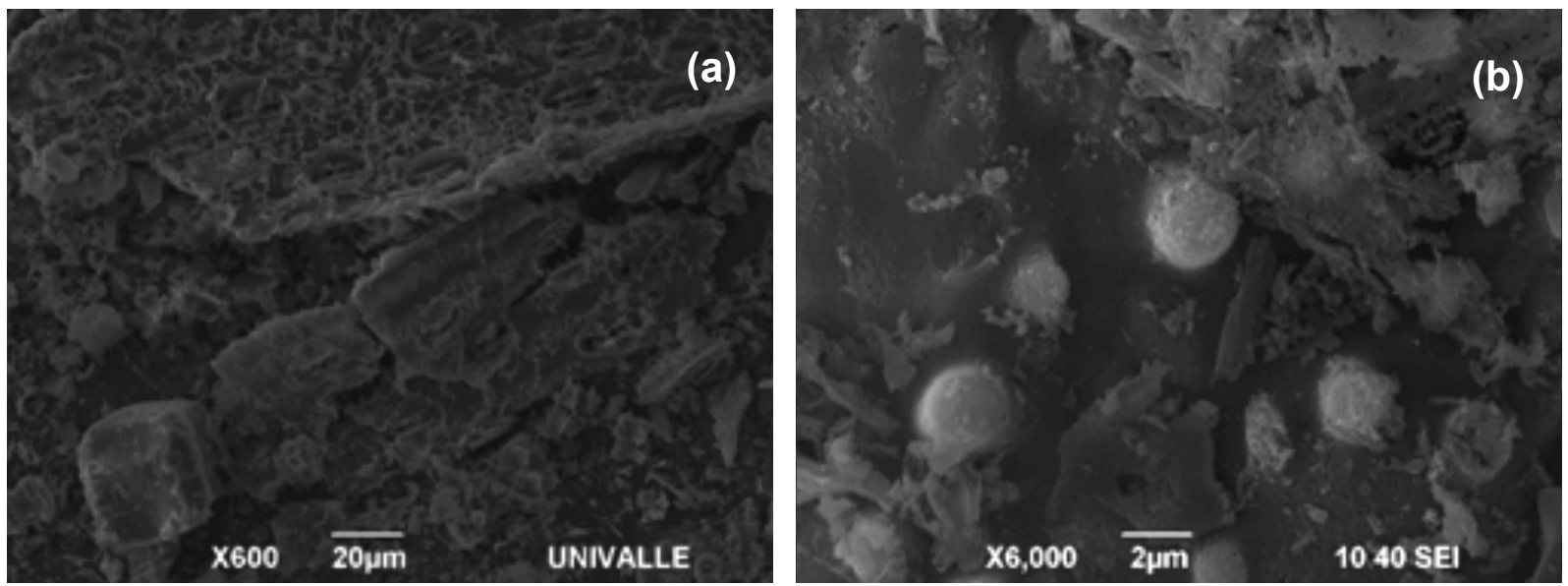

Figure 6: Wide view (X600) (a) and detailed view (X6000) (b) of RSA, obtained from calcination Process A $\left(500{ }^{\circ} \mathrm{C}\right)$.

[Figura 6: Imagem obtida por MEV: ampla (600X) (a) e detalhada (6000X) (b) de RSA obtida após calcinação - Processo A (500 ${ }^{\circ} \mathrm{C}$.]
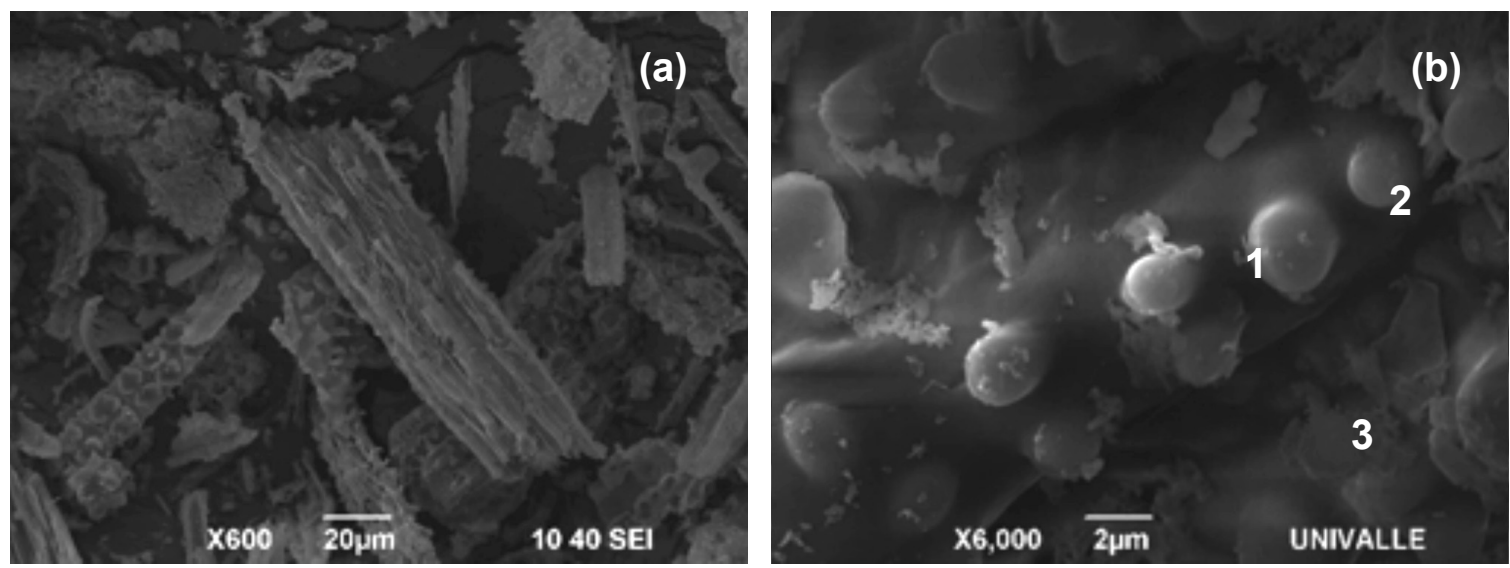

\begin{tabular}{|c|c|c|c|}
\hline Point & $\mathrm{O}$ & $\mathrm{Si}$ & Total \\
\hline 1 & 61.14 & 38.86 & 100.00 \\
\hline 2 & 62.07 & 37.93 & 100.00 \\
\hline 3 & 54.27 & 45.73 & 100.00 \\
\hline
\end{tabular}

Figure 7: Wide view (X600) (a), detailed view (X6000) (b) and EDS analysis (c) of RSA obtained from calcination Process B (600 ${ }^{\circ} \mathrm{C}$ ). [Figura 7: Imagem obtida por MEV: ampla $(600 \mathrm{X})($ a $)$ e detalhada $(6000 \mathrm{X})(\mathrm{b})$ e EDS $(c)$ de RSA obtida após calcinação - Processo B $\left(600{ }^{\circ} \mathrm{C}\right.$.] 

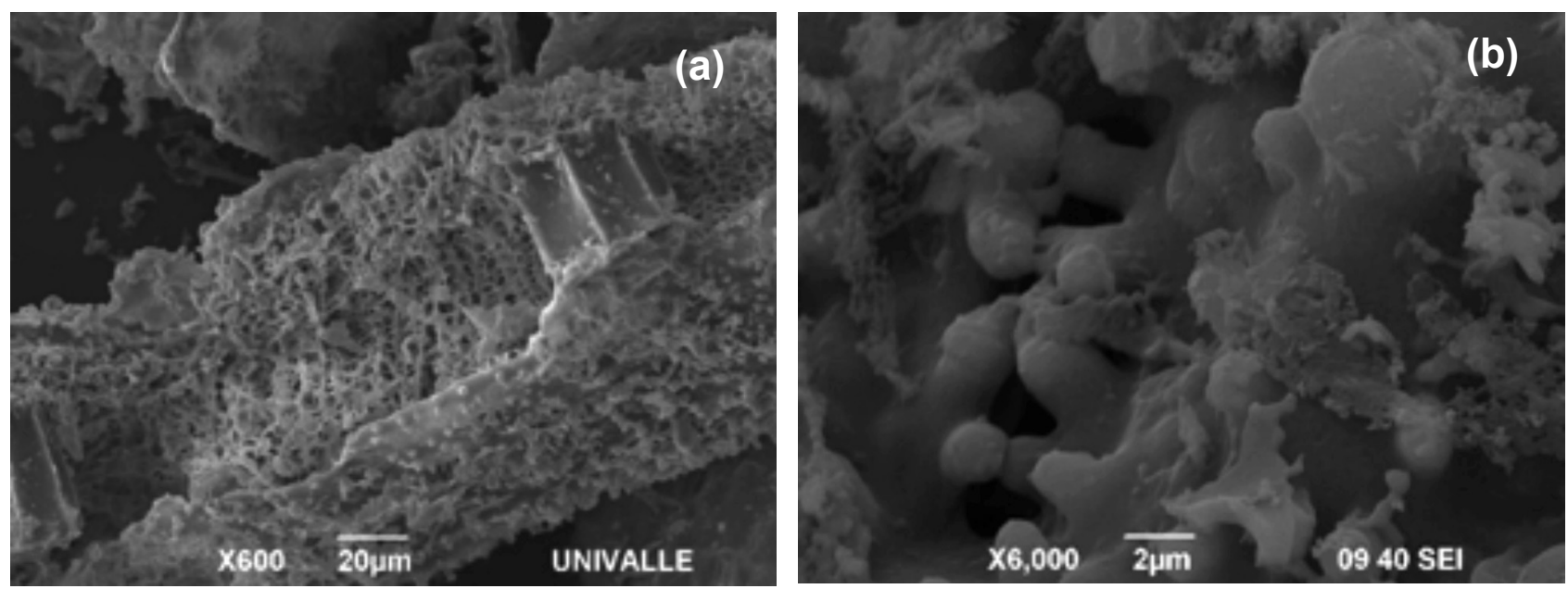

Figure 8: Wide view (X600) (a) and detailed view (X6000) (b) of RSA obtained from calcination Process C $\left(700{ }^{\circ} \mathrm{C}\right)$.

[Figura 8: Imagem obtida por MEV: ampla (600X) (a) e detalhada (6000X) (b) RSA obtida após calcinação - Processo C (700 ${ }^{\circ} \mathrm{C}$.]
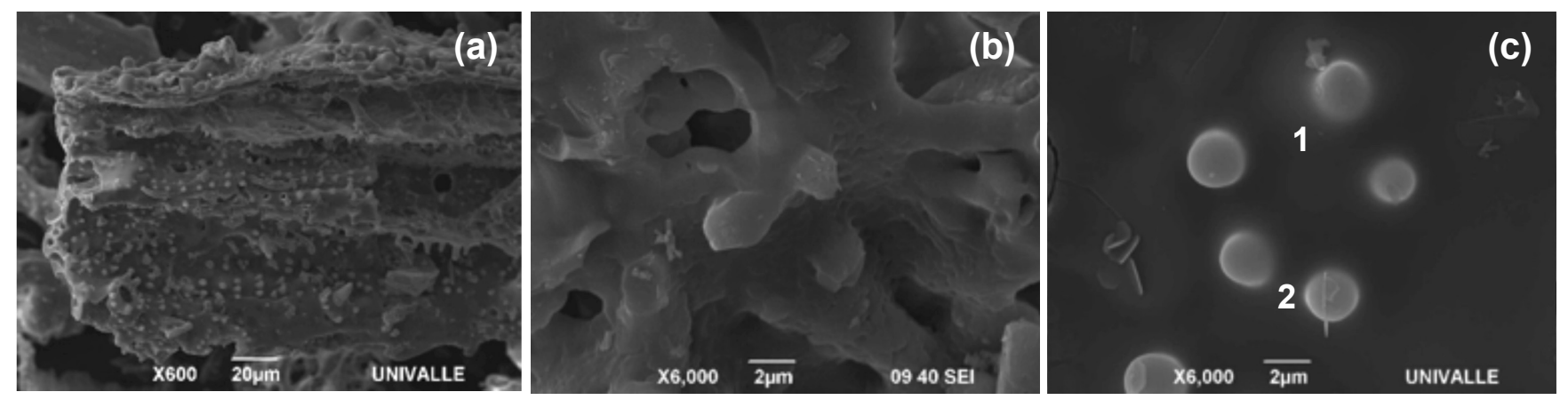

\begin{tabular}{|l|l|l|l|}
\hline Point & $\mathrm{O}$ & $\mathrm{Si}$ & Total \\
\hline 1 & 64.82 & 35.18 & 100.00 \\
\hline 2 & 52.87 & 47.13 & 100.00 \\
\hline
\end{tabular}

Figure 9: Wide view (X600) (a), detailed view (X6000) (b) and EDS analysis (c) of RSA obtained from calcination Process D (800 ${ }^{\circ} \mathrm{C}$ ). [Figura 9: Imagem obtida por MEV: ampla (600X) (a) e detalhada (6000X) (b) e EDS (c) de RSA obtida após calcinação - Processo D $\left(800^{\circ} \mathrm{C}.\right]$
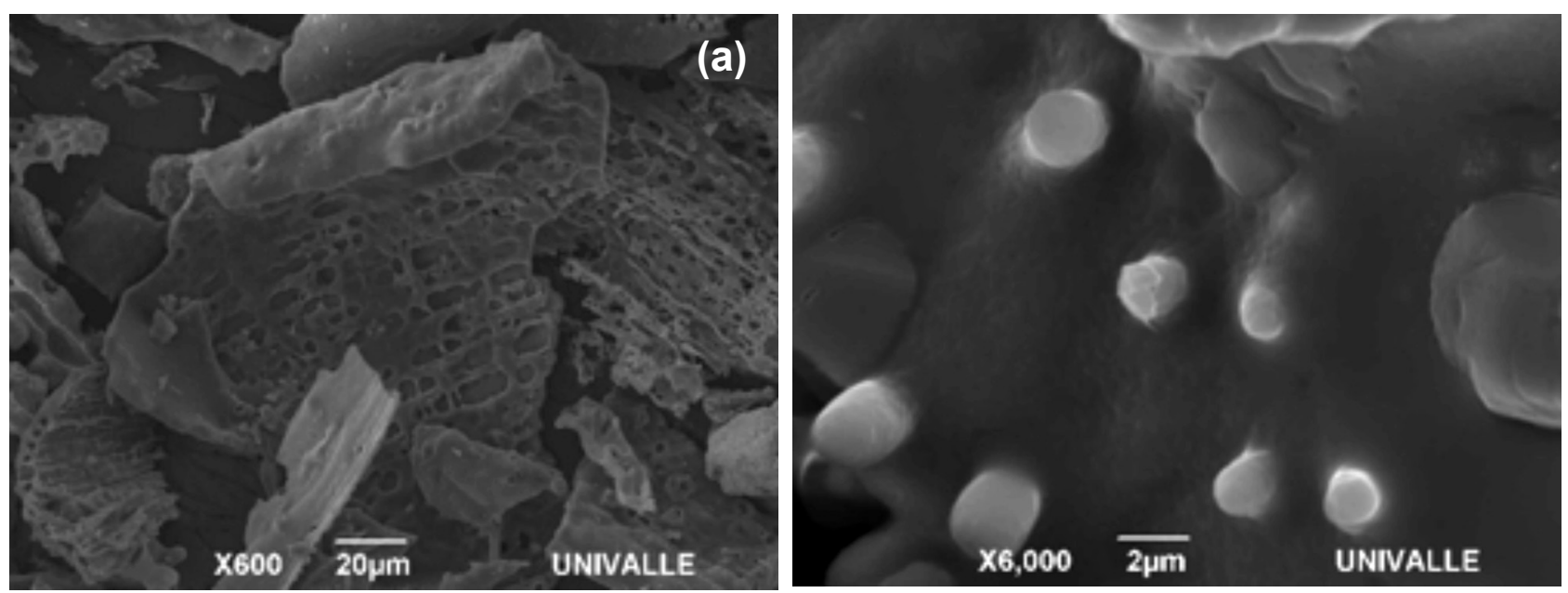

Figure 10: Wide view (X600) (a) and detailed view (X6000) (b) of RSA obtained from calcination Process E $\left(900{ }^{\circ} \mathrm{C}\right)$.

[Figura 10: Imagem obtida por MEV: ampla (600X) (a) e detalhada (6000X) (b) de RSA obtida após calcinação - Processo E (900 ${ }^{\circ} \mathrm{C}$.] 

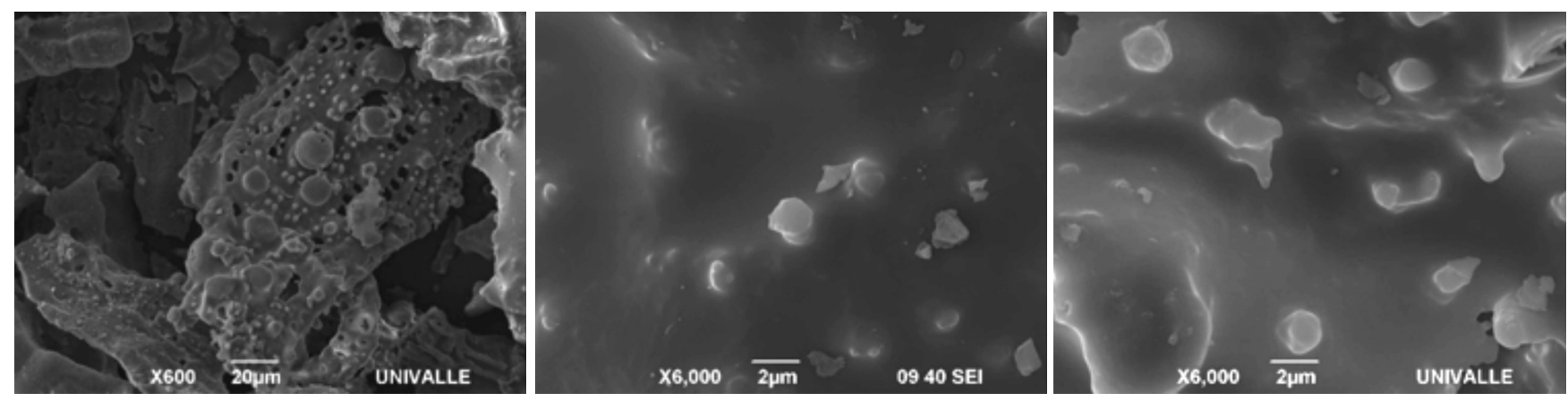

\begin{tabular}{|c|c|c|c|}
\hline Point & $\mathrm{O}$ & $\mathrm{Si}$ & Total \\
\hline 1 & 64.83 & 35.17 & 100.00 \\
\hline 2 & 60.81 & 39.19 & 100.00 \\
\hline 3 & 55.93 & 44.07 & 100.00 \\
\hline
\end{tabular}

Figure 11: Wide view (X600) (a), detailed view (X6000) (b) and EDS analysis (c) of RSA obtained from calcination Process F (1000 ${ }^{\circ} \mathrm{C}$ ). [Figura 11: Imagem obtida por MEV: ampla (600X) (a) e detalhada (6000X) (b) e EDS (c) de RSA obtida após calcinação - Processo F $\left(1000^{\circ} \mathrm{C}.\right]$

ashes. The morphology of ashes obtained at calcination temperatures equal to or greater than $800{ }^{\circ} \mathrm{C}$ shows the appearance of a molten material with protrusions on the surface, corresponding to silicon grains that have not yet dissolved in the molten material $\left(900{ }^{\circ} \mathrm{C}\right)$ and to some that have dissolved only partially $\left(1000^{\circ} \mathrm{C}\right)$. The presence of a molten material has also been reported by authors such as Yanfen, Guang and Xiaoqian [31] and Fu et al. [32].

\section{Color}

The color of rice straw ashes obtained in the different calcination processes (Fig. 12) allowed to observe that it turns from grey to whitish-grey for the ashes obtained through the calcination processes from $\mathrm{CRS}$ to $\mathrm{C}\left(700{ }^{\circ} \mathrm{C}\right)$, whereas those obtained from Processes $\mathrm{D}\left(800{ }^{\circ} \mathrm{C}\right)$ to $\mathrm{F}$ $\left(1000{ }^{\circ} \mathrm{C}\right)$ tended to turn pink.

These results are in agreement with the findings obtained by Jenkins, Bakker and Wei [14] and Thy et al. [17], who reported that the ash from rice straw that has been subjected to leaching by water to extract potassium and chlorine uniformly exhibits a bright white color. So, the RSA color is strongly related to the concentration of potassium in it.

\section{Ash fusion test samples}

With the goal of obtaining an alternative raw material from the RS to be used in the production of triaxial ceramics (clay/silica/feldspar mixtures) employed in the construction industry, it is convenient to work with an ash that has high contents of alkaline oxides $\left(\mathrm{Na}_{2} \mathrm{O}\right.$ and $\left.\mathrm{K}_{2} \mathrm{O}\right)$ and earth alkaline oxides $(\mathrm{CaO}$ and $\mathrm{MgO})$, as these are the most efficient elements for the promotion of fusion and the formation of the liquid phase. In addition, the ash must present a moderate $\mathrm{SiO}_{2}$ content to be applicable as a filler, and a low chlorine content in order to avoid incrustations, slags, and

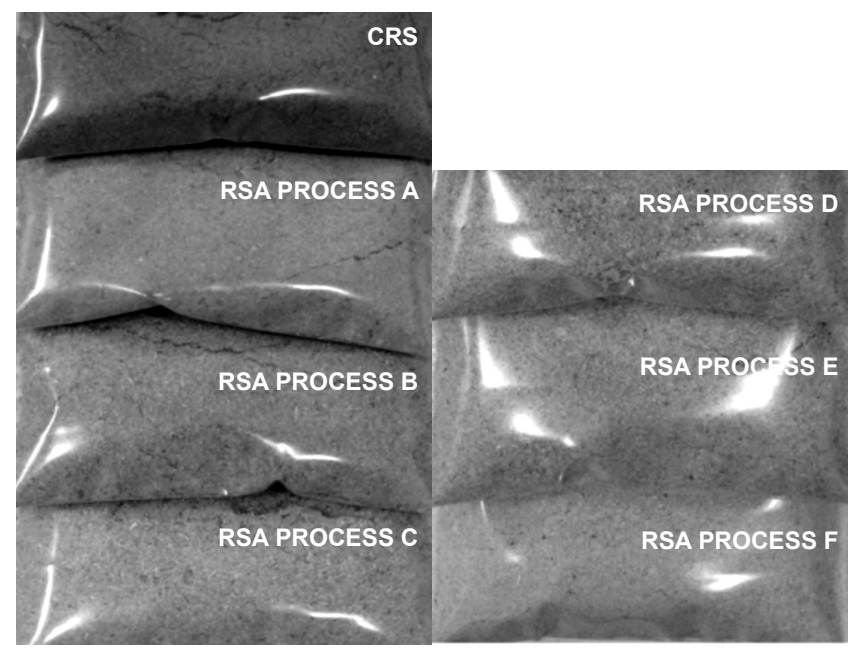

Figure 12: Color variation of rice straw ashes obtained from the different calcination processes. The ash samples are contained in plastic bags.

Figura 12: Variação de cor das cinzas da palha de arroz obtida em diferentes processos de calcinação. As amostras das cinzas estão em sacos plásticos.]

high-temperature corrosion in the furnace. Based on these results, the RSA best suited for potential use as fluxing agent and as an inert raw material is that obtained from calcination Process $\mathrm{D}-$ that is, a calcination temperature of $800{ }^{\circ} \mathrm{C}$ and a residence time of $2 \mathrm{~h}-$ because it presents a low $\mathrm{Cl}$ content $(0.59 \%)$ and high contents of alkaline oxides $\left(\mathrm{K}_{2} \mathrm{O}\right)$ $(10.53 \%)$ and earth alkaline oxides $(\mathrm{CaO})(2.80 \%)$. In order to check the fluxing character of RSA prepared in suitable conditions, a priori, the melting cylinder test from a mixture of sodium feldspar and RSA was performed, as indicated in section 2.2. The test was performed comparatively with a sample of the same sodium feldspar, whose chemical composition is detailed in Table III.

Fig. 13 shows the ash fusion test samples of sodium 
Table III - Chemical composition of the sodium feldspar and RSA Process D.

[Tabela III - Composição química do feldspato sódico e do RSA do processo $D$.]

\begin{tabular}{ccc}
\hline \multirow{2}{*}{$\begin{array}{c}\text { Element and } \\
\text { or Compound }\end{array}$} & \multicolumn{2}{c}{ Weight Concentration (\%) } \\
\cline { 2 - 3 } & $\begin{array}{c}\text { Sodium } \\
\text { Feldspar }\end{array}$ & RSA Process D \\
\hline $\mathrm{SiO}_{2}$ & 70.00 & 79.62 \\
$\mathrm{Al}_{2} \mathrm{O}_{3}$ & 18.00 & 0.27 \\
$\mathrm{Fe}_{2} \mathrm{O}_{3}$ & 0.08 & 0.26 \\
$\mathrm{CaO}$ & 0.50 & 2.80 \\
$\mathrm{MgO}$ & 0.10 & 0.89 \\
$\mathrm{Na}_{2} \mathrm{O}$ & 9.70 & 0.35 \\
$\mathrm{~K}_{2} \mathrm{O}$ & 0.35 & 10.53 \\
$\mathrm{TiO}_{2}$ & 0.11 & - \\
$\mathrm{MnO}$ & - & 0.71 \\
$\mathrm{P}_{2} \mathrm{O}_{5}$ & - & 1.61 \\
$\mathrm{Cl}$ & - & 0.59 \\
$\mathrm{~S}$ & - & 1.74 \\
$\mathrm{Zn}$ & - & 0.01 \\
$\mathrm{Rb}$ & - & 0.01 \\
$\mathrm{Sr}$ & - & 0.01 \\
$\mathrm{Cu}$ & - & 0.01 \\
$\mathrm{PF}$ & 0.50 & 0.59 \\
\hline
\end{tabular}

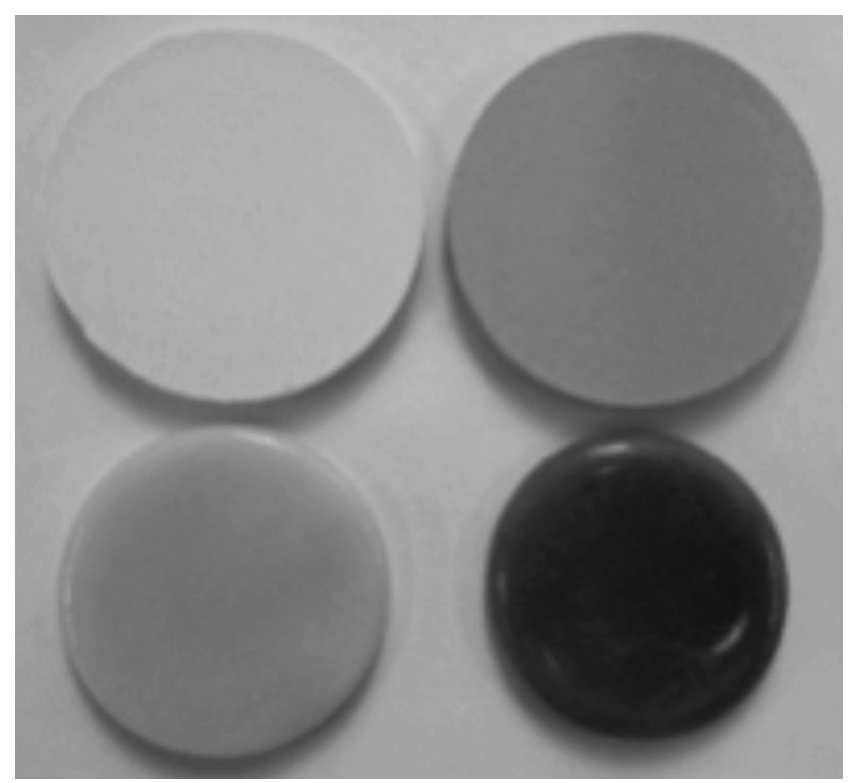

Figure 13: Melting cylinder samples before (top) and after (bottom) the sintering process, with compositions of sodium feldspar (left) and $50 \%$ sodium feldspar $+50 \%$ RSA Process D (right).

[Figura 13: Amostras cilíndricas fundidas antes (acima) e após (abaixo) o processo de sinterização, com composições de feldspato sódico (esquerda) e 50\% de feldspato sódico + 50\% RSA do processo D (direita).] feldspar compound and those of the 50\% sodium feldspar $+50 \%$ CRS Process D, before (top) and after (bottom) the sintering process.

For both compositions, it is observed that the edges are rounded after the sintering process, showing the fluxing character of both the feldspar and RSA Process D. In addition, based on the shrinkage of the samples after the sintering process, a stronger fluxing behavior is observed in samples with a composition of $50 \%$ sodium feldspar $+50 \%$ RSA Process D, which shows the strong fluxing character of RSA Process D. Regarding the sample color, those with a sodium feldspar composition presented a cream color, whereas those with a $50 \%$ sodium feldspar $+50 \%$ RSA Process D composition presented a violet color, characteristic of RSA Process D, or darker, it can be attributed to the higher content of $\mathrm{Fe}_{2} \mathrm{O}_{3}$ in theRSA (Table III).

\section{CONCLUSIONS}

From the obtained results including the chemical and mineralogical composition, it is concluded that RSA is a new alternative ceramic raw material that can be used as a replacement for the fluxing (mainly feldspar) and inert (quartz) materials that are used in the production of triaxial ceramics, including those used in some construction materials (tiles). The most suitable RSA for this purpose is that obtained at a calcination temperature of $800{ }^{\circ} \mathrm{C}$ and a residence time at this temperature of $2 \mathrm{~h}$, as it presents a low chlorine content $(0.59 \%)$ and an elevated content of $\mathrm{SiO}_{2}(79.62 \%)$, alkaline oxides $\left(\mathrm{K}_{2} \mathrm{O}\right)(10.53 \%)$ and earth alkaline oxides $(\mathrm{CaO})(2.80 \%)$. This sample also exhibits a suitable sintering behavior to be used as raw material in partial replacement of sodium feldspar usually employed in the aforementioned ceramic compositions.

\section{ACKNOWLEDGEMENTS}

The authors would like to thank Universidad del Valle (Colombia), Instituto de TecnologíaCerámica (ITC) and COLCIENCIAS for their support for the development of this project. In particular, in this publication, we present partial results from the research project "Triaxial ceramics based on rice straw ash", code 110652128358, supported by COLCIENCIAS, Official Call 521 of 2010, contract RC. No. 325-2011.

\section{REFERENCES}

[1] FAOSTAT, Rice, Paddy / Production. (2011), available at: <http://faostat.fao.org/site/567/default.aspx\#ancor>, consulted on March 01, 2013.

[2] H. J. Martínez, X. Acevedo, C. F. Espinal, "The rice chain in Colombia - A global look at its structure and dynamics 1991 - 2005", Ministerio de Agricultura y Desarrollo Rural, Observatorio Agrocadenas Colombia, 89 (2005), available at <ftp://ftp.unicauca.edu.co/cuentas/. cuentasbajadas29092009/faca/docs/Noe/Noe/ARROZ/ 
caracterizacion_arroz.pdf > consulted on April 01, 2014. [3] K. Karimi, G. Emitiazi, J. Mohammad, J. Taherzadeh, "Production of ethanol and mycelial biomass from rice straw hemicellulose hydrolyzate by Mucorindicus Process", Biochem. 41 (2006) 653-658.

[4] K. L. Kadam, L. H. Forrest, W. A. Jacobson, "Rice straw as a lignocellulosic resource: collection, processing, transportation, and environmental aspects", Biomass Bioenergy 18 (2000) 369-389.

[5] M. A. Cuevas, "Rice straw: A by-product for sustainability", Rev. Arroz (2008), available at <http://www.fedearroz. com.co/arroz/448/resumen.shtml>, consulted on January 01, 2012.

[6] Ministerio del Medio Ambiente, "Environmental guide of rice", Soc. Agric. Colombia - SAC, Federación Nacional de Arroceros - FEDEARROZ (2005), available at <http:// www.siame.gov.co/siame/documentos/Guias Ambientales/ Gu\%C3\%ADas\%20Resoluci\%C3\%B3n\%201023\%20 del $\% 2028 \% 20$ de $\% 20$ julio\%20de $\% 202005 /$ AGRICOLA $\%$ 20 Y \% 20 PECUARIO/Guia\%20Ambiental\%20para\%20 el\%20subsector\%20arrocero.pdf>, consulted on April 01, 2014.

[7] X. T. Nguyen, "The need for improved utilization of rice straw as feed for ruminants in Vietnam: An overview", Livestock Res. Rural Develop. 10 (1998), available at <http://www.lrrd.org/lrrd10/2/trach102.htm>, consulted on July 10, 2014.

[8] S. Hiziroglu, S. Jarusombuti, P. Bauchongkol, V. Fueangvivat, "Overlaying properties of fiberboard manufactured from bamboo and rice straw", Ind. Crops Prod. 28 (2008) 107-111.

[9] A. Rodríguez, A. Moral, L. Serrano, J. Labidi, L. Jiménez, "Rice straw pulp obtained by using various methods", Bioresour. Technol. 99 (2008) 2881-2886.

[10] M. M. Elwan, M. S. Attriss, A. A. Mahmoud, A. S. Salem, "Characterization of rice straw/ash and using in clay bricks", Proc. $1^{\text {st }}$ Sci. Environmental Conf. (2006) 79-92, available at <http://www.science.zu.edu.eg/\%D9\% $85 \% \mathrm{D} 8 \%$ A 4\%D8\%AA $\%$ D $\% 85 \%$ D $8 \%$ B1\%20\%D8\%A $7 \%$ D9\%84\%D8\%A8\%D9\%8A\%D8\%A6\%D8\%A9\%20 $\%$ D8\%A7\%D9\%84\%D8\%A3\%D9\%88\%D9\%84/7.pdf>, consulted on June 2, 2013.

[11] A. E. S. Mohamed, M. E. S. Taher, "Physical and Chemical Properties of Rice Straw Ash and its Effect on the Cement Paste Produced from Different Cement Types", J. King Saud Univ. 19 (2006) 21-30.

[12] F. Tanglao, P. N. Javier, A. L. Robles, "Compressive strength of concrete blended with calcined rice straw ash", in $3^{\text {rd }}$ ACF Int. Conf. - ACF/VCA. A.63 (2008).

[13] Univ. California Cooperative Extension, Rice Straw Management, (2007), available at <http:/groups.ucanr. org/ riceprojucanrorg/Rice_Production in_California/Rice straw_management.htm>, consulted on April 1, 2009.

[14] B. M. Jenkins, R. R. Bakker, J. B. Wei, "On the properties of washed straw", Biomass Bioenergy 10 (1996) 177-200.

[15] T. R. Miles, T. R. Miles Jr, L. L. Baxter, R. W.Bryers, B.
M. Jenkins, L. L. Oden, "Boiler deposits from firing biomass fuels", Biomass Bioenergy 10 (1996) 125-138.

[16] B. M. Jenkins, L. L. Baxter, T. R. Miles Jr, T. R. Miles, "Combustion properties of biomass", Fuel Process. Technol. 54 (1998) 17-46.

[17] P. Thy, B. M. Jenkins, S. Grundvig, R. Shiraki, C. E. Lesher, "High temperature elemental losses and mineralogical changes in common biomass ashes", Fuel 85 (2006) 783-795.

[18] P. Thy, B. M. Jenkins, Ch. E. Lesher, S. Grundvig, "Compositional constraints on slag formation and potassium volatilization from rice straw blended wood fuel", Fuel. Process. Technol. 87 (2006) 383-408.

[19] C. A. Arcos, D. P. Macíaz, P. J. E. Rodríguez, "Rice peel as a source of $\mathrm{SiO}_{2}$, Rev. Fac. Ing. Univ. Antioquia 41 (2007) 7-20, available at <http://www.redalyc.org/ pdf/430/43004102.pdf>, consulted onJune 2, 2014.

[20] ASTM C114-10, "Standard Test Methods for Chemical Analysis of Hydraulic Cement", Am. Soc. Testing Mater., West Conshohocken, PA, USA (2010).

[21] P. Mehta, Belgian Patent 802909, July 1973.

[22] G. Chen, J. Andries, H. Spliethoff, D. Y. C. Leung, "Experimental Investigation of Biomass Waste (Rice Straw, Cotton Stalk, and Pine Sawdust) Pyrolysis Characteristics", Energy Sources 25 (2003) 331-337.

[23] L. F. Calvo, M. Otero, B. M. Jenkins, A. Morán, A. I. García, "Heating process characteristics and kinetics of rice straw in different atmospheres", Fuel Process Technol. 85 (2004) 279-291.

[24] M. M. Nassar, "Thermal analysis kinetics of bagasse and rice straw", Energy Sources 20 (1998) 831-837.

[25] P. A. Jensen, F. J. Frandsen, K. Dam-Johansen, B. Sander, "Experimental investigation of the transformation and release to gas phase of potassium and chlorine during straw pyrolysis", Energy Fuels 14 (2000) 1280-1285.

[26] L. Hindiyarti, "Gas phase sulfur, chlorine and potassium chemistry in biomass combustion", Ph.D Thesis, CHEC Res. Centre, Dept. Chem. Eng., Technical University of Denmark, Denmark (2007).

[27] P. Fu, S. Hu, J. Xiang, L. Sun, T. Yang, A. Zhang, J. Zhang, "Mechanism study of rice straw pyrolysis by Fourier transform infrared technique", Chin. J. Chem. Eng. 17 (2009) 522-529.

[28] P. Fu, S. Hu, J. Xiang, P. Li, D. Huang, L. Jiang, A. Zhang, J.Zhang, "FTIR study of pyrolysis products evolving from typical agricultural residues", J. Anal. Appl. Pyrolysis 88 (2010) 117-123.

[29] G. Socrates, Infrared and Raman Characteristics Group Frequencies, $3^{\text {rd }}$ Ed., Chichester: John Wiley \& Sons, Ltd, (2004).

[30] R. Stahl, A. B. Ramadan, "Fuels and Chemicals from Rice Straw in Egypt" (2007), available at <http:// bibliothek. fzk.de/zb/berichte/FZKA7361.pdf>, consulted on July 16, 2014.

[31] L. Yanfen, Y. Guang, M. Xiaoqian, "Experimental Study on the Combustion Characteristics and Alkali Transformation Behavior of Straw", Energy Fuels 26 (2012) 
910-916.

[32] P. Fu, S. Hu, J.Xiang, L. Sun, S. Su, J. Wang, "Evaluation of the porous structure development of chars from pyrolysis of rice straw: Effects of pyrolysis temperature and heating rate", J. Anal. Appl. Pyrolysis 98 (2012) 177-183.

(Rec. 11/11/2014, Ac. 06/01/2015) 